\title{
EVALUASI IMPLEMENTASI PROGRAM KESELAMATAN JALAN OK BOS DI JAWA TIMUR DALAM MENURUNKAN KEJADIAN KECELAKAAN LALU LINTAS
}

\section{Implementation Evaluation of the "OK BOS" Road Safety Program in East Java for Reducing Traffic Accidents}

\author{
Sonya Sulistyono \\ Jurusan Teknik Sipil \\ Universitas Jember \\ Jl. Kalimantan 37 \\ Jember, Jawa Timur \\ sonya.sulistyono@unej.ac.id \\ Heri Wahono \\ Direktorat Lalu Lintas \\ Kepolisian Daerah Jawa Timur \\ Jl. Ahmad Yani No.116 \\ Surabaya, Jawa Timur
}

\author{
Nunung Nuring Hayati \\ Jurusan Teknik Sipil \\ Universitas Jember \\ Jl. Kalimantan 37 \\ Jember, Jawa Timur \\ nunung.nuring@unej.ac.id
}

\author{
Budi Hendrawan \\ Direktorat Lalu Lintas \\ Kepolisian Daerah Jawa Timur \\ Jl. Ahmad Yani No.116 \\ Surabaya, Jawa Timur \\ mbudih48@gmail.com
}

\author{
Ratih Novi Listyawati \\ Jurusan Teknik Sipil \\ Universitas Jember \\ J1. Kalimantan 37 \\ Jember, Jawa Timur \\ ratihnovilistyawati@gmail.com \\ Eko Hengky Prayitno \\ Direktorat Lalu Lintas \\ Kepolisian Daerah Jawa Timur \\ Jl. Ahmad Yani No.116 \\ Surabaya, Jawa Timur \\ ekohengkyp99@gmail.com
}

\begin{abstract}
IRSMS data shows the increase in traffic accidents in 2016 reached $11 \%$ compared to the events of the previous year, and in 2017 it also increased by as much as 6\%. The East Java Regional Police together with other LLAJ stakeholders formulated the "OK BOS" Program (Opén Karo Blackspot) to improve road safety. Regencies / cities are encouraged to be more sensitive to traffic accidents that occur in their areas, and encourage the implementation of road safety activities in an effort to reduce the incidence and fatality of traffic accidents. The results of the evaluation of the implementation of the program show the effectiveness of the program against the decrease in traffic accidents. Reduction in accident rates during program implementation reached $21 \%$. Other evaluation results show that the implementation of the program is still not optimal and has not been evenly distributed, so it is necessary to plan strategies for implementation in 2019.
\end{abstract}

Keywords: road safety action, traffic accident, OK BOS road safety program, accident fatality

\begin{abstract}
Abstrak
Data IRSMS memperlihatkan peningkatan kejadian kecelakaan lalu lintas tahun 2016 mencapai 11\% dibandingkan dengan kejadian tahun sebelumnya, dan tahun 2017 masih meningkat pula sebanyak 6\%. Polda Jawa Timur bersama istansi pemangku kepentingan LLAJ lainnya merumuskan Program "OK BOS” (Opén Karo Blackspot) untuk meningkatkan Kamseltibcar Lantas. Kabupaten/kota didorong lebih peka terhadap kecelakaan lalu lintas yang terjadi di wilayahnya, serta mendorong pelaksanaan kegiatan-kegiatan keselamatan jalan sebagai upaya untuk menurunkan kejadian dan fatalitas kecelakaan lalu lintas. Hasil evaluasi implementasi program memperlihatkan efektivitas program terhadap turunnya angka kecelakaan lalu lintas. Reduksi angka kecelakaan selama implementasi program mencapai $21 \%$. Hasil evaluasi lain memperlihatkan bahwa implementasi program masih belum maksimal dan belum merata, sehingga perlu dilakukan perencanaan strategi untuk implementasi pada tahun 2019.
\end{abstract}

Kata kunci: aksi keselamatan jalan, kecelakaan lalu lintas, program OK BOS, fatalitas kecelakaan 


\section{PENDAHULUAN}

Keselamatan jalan telah menjadi masalah global dimana lebih dari 1,24 juta orang meninggal dan lebih dari 50 juta orang luka karena kecelakaan lalu lintas di jalan, sementara $75 \%$ kejadian dan dampaknya terjadi di negara-negara berkembang. (WHO, 2013). Sementara di Uni Eropa pada tahun 2012 korban meninggal karena kecelakaan mencapai 2.700 orang dengan korban luka parah sebanyak 313.000 (European Transport Safety Council, 2013). Resolusi PBB pada tahun 2010 telah dikeluarkan untuk secara bersama melakukan aksi nyata menurunkan kecelakaan lalu lintas yang terjadi di dunia, dengan mencanangkan Dekade Aksi Keselamatan Jalan 2011 - 2020 (WHO, 2011). Pemerintah Indonesi menindak lanjuti hal dan mendukung resolusi tersebut, dengan diterbitkannya Inpres Nomor 4 tahun 2013, tentang Dekade Aksi Keselamatan Jalan (DAKJ). Dalam Rencana Umum Nasional Keselamatan Jalan (RUNK) 2011 - 2035 disebutkan bahwa Program DAKJ merupakan bagian RUNK pada short term pertama.

Jawa Timur merupakan salah satu provinsi di Indonesia dengan pertumbuhan ekonomi paling tinggi di Indonesia. Data BPS Provinsi Jawa Timur mencatat bahwa pertumbuhan yang terjadi tahun 2016 dan 2017 mencapai 5,55\% dan 5,6\% (BPS Provinsi Jawa Timur, 2017 dan 2018). Pertumbuhan ekonomi yang positif tersebut tentunya meningkatkan pergerakan lalu lintas. Namun fakta yang lain berkata berbeda. Potret kejadian kecelakaan lalu lintas di Jawa Timur, berdasarkan data IRSMS, memperlihatkan jumlah kejadian kecelakaan lalu lintas yang tertinggi di Indonesia. Pada tahun 2017 terjadi 4.897 kejadian kecelakaan fatal dari 24.371 kejadian kecelakaan lalu lintas dan pada tahun 2016 terjadi 23.101 kejadian kecelakaan lalu lintas dengan 4.982 kejadian kecelakaan fatal. Sementara peningkatan kejadian kecelakaan pada tahun 2016 mencapai 11\% dibandingkan kejadian pada tahun sebelumnya, dan pada tahun 2017 masih meningkat pula sebesar $6 \%$. Kecelakaan fatal tahun 2016 meningkat 5\% dibandingkan kejadian pada tahun sebelumnya, dan pada tahun 2017 hanya terjadi penurunan sebesar $2 \%$. Kondisi ini perlu menjadi perhatian instansi terkait, karena masih terjadi kontra produktif dengan arah kebijakan RUNK, yang di dalamnya mengimplementasikan pula Inpres Nomor 4 Tahun 2013, yang menterjemahkan Resolusi PBB tentang Dekade Aksi Keselamatan Jalan.

Tinjauan terhadap implementasi program aksi keselamatan jalan di Jawa Timur dan hasil evaluasinya telah dikaji beberapa peneliti sebelumnya. Hayati, dkk. (2010) memaparkan implementasi program keselamatan jalan dengan meningkatkan patroli polisi lalu lintas dan karakter lingkungan jalan pada lokasi blackspot dilakukan Polres Jember sepanjang September - Desember 2008. Hasil evaluasi memperlihatkan kegiatan yang dilakukan cukup berhasil, dimana nilai X2 $=0,00685$ berada diluar X2tabel dengan nilai $\mathrm{K}$ sebesar $0,78<1$. Sementara Supriono, dkk. (2010) melakukan analisis penganan kecelakaan pada lokasi rawan kecelakaan (blacksite) dilakukan disepanjang Jl. Gadjah Mata Perkotaan Jember yang merupakan lokasi Kawasan Tertib Lalu Lintas (KTL). Hasil evaluasi memperlihatkan efektivitas penanganan kecelakaan memberikan hasil maksimal pada periode ketika penanganan (2008) dan setelah penanganan (2009). Terjadi penurunan nyata terhadap kejadian kecelakaan dengan efektivitas penanganan mencapai 56\%. Sedangkan Sulistyono, dkk. (2012) melakukan tinjauan terhadap implementasi program keselamatan jalan Partnership Road Safety Action (PRSA) pada Jalur Pantura Surabaya - Tuban pada Juni hingga Desember 2010. Hasil evaluasi memperlihatkan, keberhasilan implementasi program PRSA ditunjukkan Polres Gresik dimana jumlah kecelakaan yang terjadi mengalami penurunan signifikan sebesar $63,61 \%$ dengan nilai $\mathrm{X} 2=9,819$. Sementara pada Polres Lamongan dan Polres Tuban tidak demikian. 
Undang-Undang Nomor 22 Tahun 2009 menyebutkan bahwa keselamatan jalan adalah suatu keadaan terhindarnya setiap orang dari risiko kecelakaan selama berlalu lintas yang disebabkan oleh manusia, kendaraan, jalan, dan/atau lingkungan. Disebutkan pula bahwa Polisi Lalu Lintas bertanggung jawab atas keselamatan di jalan dan berlalu lintas, termasuk di dalamnya pengumpulan, pemantauan, pengolahan, penyajian data lalu lintas dan angkutan jalan, serta penegakan hukum. Menyikapi hal tersebut, Direktorat Lalu Lintas Polda Jawa Timur bersama istansi pemangku kepentingan LLAJ lainnya merumuskan program keselamatan jalan untuk meningkatkan Kamseltibcar Lantas dalam Program OK BOS (Opén Karo Blackspot). Melalui program ini kabupaten/kota didorong untuk lebih peka dalam melihat kecelakaan yang terjadi dan kegiatan-kegiatan keselamatan jalan didorong sebagai upaya untuk menurunkan kejadian dan fatalitas kecelakaan. Selain itu, melalui program ini kabupaten/kota didorong pula untuk menangani lokasi-lokasi rawan kecelakaan di wilayahnya.

Penelitian ini dilakukan untuk menganalisis efektivitas implementasi Program OK BOS pada tahap awal dalam menurunkan kejadian dan fatalitas kecelakaan. Data kecelakaan yang digunakan akan merujuk data IRSMS, karena Tjahjono (2017) menyampaikan bahwa evaluasi terhadap keselamatan jalan haruslah berbasis data kecelakaan lalulintas yang didapat dari IRSMS Korlantas Polri. Hal ini menjadi penting untuk memberikan kesamaan persepsi data kecelakaan yang digunakan. Sehingga hasil penelitian ini diharapkan dapat digunakan untuk mengarahkan strategi dalam implementasi program selanjutnya pada tahun 2019.

\section{METODE PENELITIAN}

Penelitian ini bertujuan melakukan evaluasi terhadap implementasi Program OK BOS Ditlantas Polda Jawa Timur. Perencanaan program dilaksanakan pada April - Mei 2018 dan implementasi dilakukan mulai bulan Juni 2018. Tahap awal implementasi program dilaksanakan sepanjang periode Juni - Oktober 2018. Komparasi pada penelitian ini dilakukan sebelum dan saat program diimplementasikan.

\section{Analisis Statistika Kecelakaan}

Analisis statistika kecelakaan merupakan suatu metode untuk melakukan evaluasi terhadap kecelakaan yang terjadi. Evaluasi efektivitas implementasi Program OK BOS di Jawa Timur pada penelitian ini menggunakan metode analisis statistika kecelakaan Chi-Square Test untuk kondisi sebelum dan saat implementasi program. Sedangkan K-Test digunakan untuk analisis tingkat efektivitas kegiatan aksi keselamatan dalam implementasi Program OK BOS yang telah dilakukan.

1. Analisis Sebelum dan Sesudah Penanganan

Departemen Permukiman dan Prasarana Wilayah (2004) menyebutkan bahwa uji chikuadrat atau uji normal dapat digunakan untuk analisis statistika kecelakaan lalu lintas. Karena itu, uji statistika ini dimanfaatkan untuk menganalisis sebelum dan sesudah penanganan kecelakaan lalu lintas pada studi ini. Teknik analisis statistika kecelakaan ini dapat dijelaskan sebagai berikut:

a. Variabel

Variabel atau tipe keelakaan sejenis harus ditentukan. Variabel yang ditentukan ini antara lain untuk site (lokasi yang diamati) dan control (keseluruhan lokasi di luar lokasi yang ditinjau). 
b. Hipotesis

$\mathrm{H}_{0}$ : tidak terdapat perbedaan yang berarti antara jumlah angka kecelakaan pada grup kecelakaan pada suatu lokasi rawan (site) dengan kelompok kecelakaan yang sejenis pada ruas jalan atau pada suatu area (control) secara umum.

$\mathrm{H}_{1}$ : terdapat perbedaan yang berarti.

c. Nilai Observasi Chi-Kuadrad atau Nilai Z: Nilai Observasi

Nilai ini diperoleh dengan perhitungan chi-kuadrad menggunakan tabel kontingensi 2x2, seperti yang ditunjukkan pada Tabel 1 .

Tabel 1. Tabel kontingensi $2 \times 2$.

\begin{tabular}{lccc}
\hline & Site & Control & Total \\
\hline Tipe kecelakaan $\mathrm{x}$ & $\mathrm{a}$ & $\mathrm{c}$ & $\mathrm{g}=\mathrm{a}+\mathrm{c}$ \\
\hline Tipe kecelakaan selain $\mathrm{x}$ & $\mathrm{b}$ & $\mathrm{d}$ & $\mathrm{h}=\mathrm{b}+\mathrm{d}$ \\
\hline Total & $\mathrm{e}=\mathrm{a}+\mathrm{b}$ & $\mathrm{f}=\mathrm{c}+\mathrm{d}$ & $\mathrm{n}=\mathrm{a}+\mathrm{b}+\mathrm{c}+\mathrm{d}$ \\
\hline
\end{tabular}

Persamaan chi-kuadrad $\left(\mathrm{x}^{2}\right)$ dapat dihitung dengan persamaan berikut:

$$
\left(\chi^{2}\right)=\frac{(|a d-b c|-n / 2)^{2} n}{e f g h}
$$

dengan:

$\mathrm{x}^{2}=$ nilai chi-kuadrad

$\mathrm{a}=$ proporsi tipikal kecelakaan (site)

$\mathrm{b}=$ proporsi tipikal kecelakaan lainnya (site)

$\mathrm{c}=$ proporsi tipikal kecelakaan (control)

$\mathrm{d}=$ proporsi tipikal kecelakaan lainnya (control) $\mathrm{e}, \mathrm{f}, \mathrm{g}, \mathrm{h}, \mathrm{n}$ lihat pada tabel

d. Signifikansi Pengujian

Analisis hasil uji statistika diperoleh dengan membandingkan nilai observasi dengan nilai tabel (dengan tingkat siginifikansi $\alpha$ tertentu), dengan kriteria:

1) $\mathrm{H}_{0}$ ditolak, apabila nilai observasi lebih besar dari nilai tabel.

2) Ho tidak dapat ditolak, apabila nilai observasi lebih kecil atau sama dengan nilai tabel.

2. Tingkat Efektivitas Penanganan

Uji-K dapat digunakan sebagai pendekatan untuk meninjau tingkat efektivitas penanganan kecelakaan di suatu lokasi rawan kecelakaan lalu lintas, dengan menggunakan persamaan:

$$
k=(b / a) /(d / c)
$$

dengan:

$\mathrm{a}=$ angka kecelakaan sebelum (before) penanganan pada lokasi site

$\mathrm{b}=$ angka kecelakaan sesudah (after) penanganan pada lokasi site

$\mathrm{c}=$ angka kecelakaan sebelum (before) penanganan pada lokasi control

$\mathrm{d}=$ angka kecelakaan sesudah (after) penanganan pada lokasi control

Interpretasi nilai $\mathrm{k}$ dari hasil Uji-K adalah apabila nilai $\mathrm{k}<1$ dapat diartikan terdapat penurunan kecelakaan, apabila nilai $\mathrm{k}=1$ dapat diartikan tidak terdapat penurunan, 
dan apabila nilai $\mathrm{k}>1$ dapat diartikan terdapat peningkatan kecelakaan. Sedangkan persentase tingkat penurunan atau peningkatannya dapat ditentukan dengan $(\mathrm{k}-1) \mathrm{x}$ $100 \%$.

\section{Tahapan Penelitian}

Tahapan pelaksanaan penelitian ini adalah sebagai berikut:

1. Studi pustaka; mencakup metode-metode penentuan angka kecelakaan dan analisis kecelakaan menggunakan metode statistika yang terkait dengan evaluasi terhadap pelaksanaan program keselamatan.

2. Pengumpulan data; meliputi data kecelakaan lalu lintas dari IRSMS dan data impelementasi program keselamatan dari Subdit Kamsel Ditlantas Polda Jawa Timur. Selain itu, data pendukung implementasi Program OK BOS diperoleh melalui diskusi dan wawancara.

3. Analisis Data; meliputi analisis angka kecelakaan lalu lintas dari data yang dapat dihimpun. Analisis sebelum dan saat implementasi Program OK BOS menggunakan metode statistika Chi-Square Test dan analisis efektivitas implementasi Program OK BOS menggunakan metode statistik $K$ - Test. Interpretasi hipotesis terhadap uji chikuadrad:

a. Menolak Ho berarti terdapat perbedaan yang berarti antara angka kecelakaan lalu lintas pada grup kecelakaan lalu lintas di suatu lokasi yang mengimplementasikan Program OK BOS (site) dengan kelompok tipikal angka kecelakaan sejenis di wilayah Jawa Timur (control) secara umum.

b. Tidak dapat menolak Ho berarti tidak terdapat perbedaan yang berarti antara angka kecelakaan pada grup kecelakaan lalu lintas di suatu lokasi yang mengimplementasikan Program PRSA pada Jalur Pantura Surabaya-Tuban (site) dengan kelompok tipikal angka kecelakaan sejenis pada Jalur Pantura SurabayaTuban (control) secara umum.

4. Evaluasi terhadap implementasi Program PRSA dilakukan dengan meninjau hasil analisis statistik dua metode tersebut (uji chi-kuadrad dan uji-k) terhadap angka kecelakaan lalu lintas yang terjadi ditinjau secara kuantitas dan kualitas.

\section{ANALISIS ANGKA KECELAKAAN}

Analisis angka kecelakaan digunakan sebagai suatu pendekatan untuk mengukur perbedaan yang terjadi sebelum dan saat implementasi Program OK BOS. Metode statistika chi-square $\left(\chi^{2}\right)$ digunakan dalam analisis ini. Hipotesis awal $\left(\mathrm{H}_{0}\right)$ pada analisis ini adalah tidak terdapat perbedaan yang signifikan pada angka kecelakaan sebelum dan saat dilaksanakan program OK BOS di kota/kabupaten dibandingkan dengan angka kecelakaan di Jawa Timur. Untuk analisis ini, $\mathrm{H}_{0}$ ditolak jika nilai $\chi^{2}$ hitung lebih besar dari nilai $\chi^{2}$ tabel.

Untuk analisis angka kecelakaan sebelum pelaksanaan program (periode Juni - Oktober 2017) dan saat pelaksanaan (periode Juni - Oktober 2018), digunakan tabel kontingensi $2 \times 2$. Dengan menggunakan derajat kebebasan (v) sebesar 1 dan dengan derajat kepercayaan $95 \%(\alpha=5 \%)$, diperoleh nilai $\chi^{2}$ tabel sebesar 3,84146. Hasil analisis yang diperoleh disajikan pada Tabel 2. 
Tabel 2. Angka kecelakaan sebelum dan selama implementasi Program OK BOS

\begin{tabular}{|c|c|c|c|c|c|}
\hline \multirow[b]{2}{*}{ No. } & \multirow[b]{2}{*}{ Polres } & \multicolumn{2}{|c|}{ Jumlah Kecelakaan } & \multirow[b]{2}{*}{$\mathbf{X}^{2}$ hitung } & \multirow[b]{2}{*}{ Hasil Evaluasi } \\
\hline & & $\begin{array}{c}\text { Jun - Okt } \\
2017\end{array}$ & $\begin{array}{c}\text { Jun - Okt } \\
2018\end{array}$ & & \\
\hline 1 & Kota Besar Surabaya & 628 & 509 & 13,83 & \\
\hline 2 & Pelabuhan Tj. Perak & 94 & 51 & 12,88 & H0 ditolak \\
\hline 3 & Gresik & 285 & 319 & 1,20 & H0 tidak dapat ditolak \\
\hline 4 & Sidoarjo & 584 & 669 & 3,93 & H0 ditolak \\
\hline 5 & Mojokerto Kota & 156 & 152 & 0,11 & H0 tidak dapat ditolak \\
\hline 6 & Mojokerto & 367 & 376 & 0,00 & H0 tidak dapat ditolak \\
\hline 7 & Malang Kota & 127 & 86 & 8,20 & H0 ditolak \\
\hline 8 & Malang & 391 & 307 & 11,12 & H0 ditolak \\
\hline 9 & Batu & 105 & 87 & 1,82 & H0 tidak dapat ditolak \\
\hline 10 & Pasuruan Kota & 163 & 148 & 0,91 & H0 tidak dapat ditolak \\
\hline 11 & Pasuruan & 351 & 363 & 0,02 & H0 tidak dapat ditolak \\
\hline 12 & Probolinggo Kota & 199 & 138 & 11,65 & H0 ditolak \\
\hline 13 & Probolinggo & 223 & 260 & 2,00 & H0 tidak dapat ditolak \\
\hline 14 & Jember & 464 & 536 & 3,62 & H0 tidak dapat ditolak \\
\hline 15 & Lumajang & 186 & 237 & 4,91 & H0 ditolak \\
\hline 16 & Situbondo & 129 & 153 & 1,45 & H0 tidak dapat ditolak \\
\hline 17 & Banyuwangi & 378 & 359 & 0,81 & H0 tidak dapat ditolak \\
\hline 18 & Bondowoso & 185 & 172 & 0,65 & H0 tidak dapat ditolak \\
\hline 19 & Kediri Kota & 261 & 260 & 0,04 & H0 tidak dapat ditolak \\
\hline 20 & Kediri & 539 & 577 & 0,60 & H0 tidak dapat ditolak \\
\hline 21 & Nganjuk & 364 & 325 & 2,78 & H0 tidak dapat ditolak \\
\hline 22 & Jombang & 485 & 454 & 1,53 & H0 tidak dapat ditolak \\
\hline 23 & Tulunggagung & 427 & 380 & 3,42 & H0 tidak dapat ditolak \\
\hline 24 & Blitar Kota & 111 & 84 & 3,93 & H0 ditolak \\
\hline 25 & Blitar & 167 & 193 & 1,28 & H0 tidak dapat ditolak \\
\hline 26 & Trenggalek & 189 & 224 & 2,15 & H0 tidak dapat ditolak \\
\hline 27 & Madiun Kota & 205 & 196 & 0,34 & H0 tidak dapat ditolak \\
\hline 28 & Madiun & 275 & 317 & 2,06 & H0 tidak dapat ditolak \\
\hline 29 & Ngawi & 298 & 366 & 5,39 & H0 ditolak \\
\hline 30 & Pacitan & 127 & 141 & 0,40 & H0 tidak dapat ditolak \\
\hline 31 & Ponorogo & 270 & 342 & 6,76 & H0 ditolak \\
\hline 32 & Magetan & 260 & 277 & 0,22 & H0 tidak dapat ditolak \\
\hline 33 & Bojonegoro & 475 & 390 & 9,43 & H0 ditolak \\
\hline 34 & Tuban & 567 & 769 & 25,04 & H0 ditolak \\
\hline
\end{tabular}




\begin{tabular}{|c|c|c|c|c|c|}
\hline \multirow[b]{2}{*}{ No. } & \multirow[b]{2}{*}{ Polres } & \multicolumn{2}{|c|}{ Jumlah Kecelakaan } & \multirow[b]{2}{*}{$\mathbf{X}_{\text {hitung }}^{2}$} & \multirow[b]{2}{*}{ Hasil Evaluasi } \\
\hline & & $\begin{array}{c}\text { Jun - Okt } \\
2017\end{array}$ & $\begin{array}{c}\text { Jun - Okt } \\
2018\end{array}$ & & \\
\hline 35 & Lamongan & 397 & 421 & 0,28 & H0 tidak dapat ditolak \\
\hline 36 & Sumenep & 79 & 80 & 0,00 & H0 tidak dapat ditolak \\
\hline 37 & Pamekasan & 110 & 124 & 0,49 & H0 tidak dapat ditolak \\
\hline 38 & Sampang & 60 & 51 & 0,73 & H0 tidak dapat ditolak \\
\hline 39 & Bangkalan & 81 & 73 & 0,46 & H0 tidak dapat ditolak \\
\hline & Total & 10.762 & 10.966 & & \\
\hline
\end{tabular}

Hasil analisis chi-square angka kecelakaan berdasarkan jumlah kecelakaan, pada Tabel 2, menunjukkan 12 polres jajaran menolak $\mathrm{H}_{0}$, dan 27 polres jajaran lainnya tidak dapat menolak $\mathrm{H}_{0}$. Dengan demikian dapat dikatakan bahwa pada implementasi awal Program OK BOS (periode Juni - Oktober 2018) hanya terdapat 12 polres jajaran yang mengalami perubahan atau mengalami dampak akibat penerapan program keselamatan jalan di Jawa Timur.

\section{EFEKTIVITAS IMPLEMENTASI PROGRAM}

Anaisis ini dilakukan untuk meninjau efektivitas implementasi awal Program OK BOS terhadap angka kecelakaan lalu lintas yang terjadi. Pendekatan yang dilakukan adalah dengan melakukan Uji-K (k-test). Nilai yang didapat dari uji ini menunjukkan efektivitas implementasi program. Apabila nilai k-test kurang dari 1, berarti terdapat penurunan kecelakaan lalu lintas. Namun sebaliknya jika nilai k-test lebih besar dari 1, berarti terdapat peningkatan kecelakaan, dan apabila nilai k-test sama dengan 1, berarti tidak terdapat penurunan kecelakaan lalu lintas.

Tabel 3. Efektivitas implementasi Program OK BOS

\begin{tabular}{|c|c|c|c|c|c|c|}
\hline \multirow{3}{*}{$\begin{array}{c}\text { No. } \\
1\end{array}$} & \multirow{3}{*}{$\begin{array}{c}\text { Polres } \\
\text { Kota Besar Surabaya }\end{array}$} & \multicolumn{2}{|c|}{ Jumlah Kecelakaan } & \multirow{3}{*}{$\begin{array}{c}\begin{array}{c}\text { Nilai } \\
\text { K }\end{array} \\
0,80\end{array}$} & \multirow{2}{*}{\multicolumn{2}{|c|}{ Hasil Evaluasi }} \\
\hline & & \multirow{2}{*}{$\begin{array}{c}\text { Jun - Okt } 2017 \\
628\end{array}$} & \multirow{2}{*}{$\begin{array}{c}\text { Jun - Okt } 2018 \\
509\end{array}$} & & & \\
\hline & & & & & penurunan & $-20,46 \%$ \\
\hline 2 & Pelabuhan Tj. Perak & 94 & 51 & 0,53 & penurunan & $-46,75 \%$ \\
\hline 3 & Gresik & 285 & 319 & 1,10 & peningkatan & $9,85 \%$ \\
\hline 4 & Sidoarjo & 584 & 669 & 1,12 & peningkatan & $12,42 \%$ \\
\hline 5 & Mojokerto Kota & 156 & 152 & 0,96 & penurunan & $-4,38 \%$ \\
\hline 6 & Mojokerto & 367 & 376 & 1,01 & peningkatan & $0,55 \%$ \\
\hline 7 & Malang Kota & 127 & 86 & 0,66 & penurunan & $-33,54 \%$ \\
\hline 8 & Malang & 391 & 307 & 0,77 & penurunan & $-22,94 \%$ \\
\hline 9 & Batu & 105 & 87 & 0,81 & penurunan & $-18,68 \%$ \\
\hline 10 & Pasuruan Kota & 163 & 148 & 0,89 & penurunan & $-10,89 \%$ \\
\hline 11 & Pasuruan & 351 & 363 & 1,01 & peningkatan & $1,49 \%$ \\
\hline
\end{tabular}


Traffic Accident Research Centre

\begin{tabular}{|c|c|c|c|c|c|c|}
\hline \multirow{3}{*}{$\begin{array}{c}\text { No. } \\
12\end{array}$} & \multirow{3}{*}{$\begin{array}{c}\text { Polres } \\
\text { Probolinggo Kota }\end{array}$} & \multicolumn{2}{|c|}{ Jumlah Kecelakaan } & \multirow{3}{*}{$\begin{array}{c}\begin{array}{c}\text { Nilai } \\
\text { K }\end{array} \\
0,68\end{array}$} & \multirow{2}{*}{\multicolumn{2}{|c|}{ Hasil Evaluasi }} \\
\hline & & \multirow{2}{*}{$\begin{array}{c}\text { Jun }- \text { Okt } 2017 \\
199\end{array}$} & \multirow{2}{*}{$\frac{\text { Jun }- \text { Okt } 2018}{138}$} & & & \\
\hline & & & & & penurunan & $-31,94 \%$ \\
\hline 13 & Probolinggo & 223 & 260 & 1,14 & peningkatan & $14,42 \%$ \\
\hline 14 & Jember & 464 & 536 & 1,13 & peningkatan & $13,37 \%$ \\
\hline 15 & Lumajang & 186 & 237 & 1,25 & peningkatan & $25,05 \%$ \\
\hline 16 & Situbondo & 129 & 153 & 1,16 & peningkatan & $16,40 \%$ \\
\hline 17 & Banyuwangi & 378 & 359 & 0,93 & penurunan & $-6,79 \%$ \\
\hline 18 & Bondowoso & 185 & 172 & 0,91 & penurunan & $-8,76 \%$ \\
\hline 19 & Kediri Kota & 261 & 260 & 0,98 & penurunan & $-2,24 \%$ \\
\hline 20 & Kediri & 539 & 577 & 1,05 & peningkatan & $5,06 \%$ \\
\hline 21 & Nganjuk & 364 & 325 & 0,88 & penurunan & $-12,38 \%$ \\
\hline 22 & Jombang & 485 & 454 & 0,92 & penurunan & $-8,13 \%$ \\
\hline 23 & Tulunggagung & 427 & 380 & 0,87 & penurunan & $-12,66 \%$ \\
\hline 24 & Blitar Kota & 111 & 84 & 0,74 & penurunan & $-25,73 \%$ \\
\hline 25 & Blitar & 167 & 193 & 1,13 & peningkatan & $13,42 \%$ \\
\hline 26 & Trenggalek & 189 & 224 & 1,16 & peningkatan & $16,31 \%$ \\
\hline 27 & Madiun Kota & 205 & 196 & 0,94 & penurunan & $-6,17 \%$ \\
\hline 28 & Madiun & 275 & 317 & 1,13 & peningkatan & $13,13 \%$ \\
\hline 29 & Ngawi & 298 & 366 & 1,21 & peningkatan & $20,53 \%$ \\
\hline 30 & Pacitan & 127 & 141 & 1,09 & peningkatan & $8,96 \%$ \\
\hline 31 & Ponorogo & 270 & 342 & 1,24 & peningkatan & $24,31 \%$ \\
\hline 32 & Magetan & 260 & 277 & 1,05 & peningkatan & $4,56 \%$ \\
\hline 33 & Bojonegoro & 475 & 390 & 0,81 & penurunan & $-19,42 \%$ \\
\hline 34 & Tuban & 567 & 769 & 1,33 & peningkatan & $33,10 \%$ \\
\hline 35 & Lamongan & 397 & 421 & 1,04 & peningkatan & $4,07 \%$ \\
\hline 36 & Sumenep & 79 & 80 & 0,99 & penurunan & $-0,62 \%$ \\
\hline 37 & Pamekasan & 110 & 124 & 1,11 & peningkatan & $10,63 \%$ \\
\hline 38 & Sampang & 60 & 51 & 0,83 & penurunan & $-16,58 \%$ \\
\hline 39 & Bangkalan & 81 & 73 & 0,88 & penurunan & $-11,55 \%$ \\
\hline & Total & 10.762 & 10.966 & & & \\
\hline
\end{tabular}

Hasil analisis menggunakan Uji-K yang disajikan pada Tabel 3 menunjukkan efektivitas implementasi awal Program OK BOS terjadi di 20 polres jajaran, sementara pada 19 polres jajaran lainnya tidak demikian. Dengan demikian dapat dikatakan bahwa implementasi awal Program OK BOS masih belum menunjukkan keberhasilan secara menyeluruh pada polres-polres jajaran di wilayah hukum Polda Jawa Timur. Untuk itu perlu direncanakan suatu strategi implementasi program yang lebih baik pada tahap selanjutnya. 


\section{SIGNIFIKANSI PERBEDAAN IMPLEMENTASI PROGRAM}

Uji beda berpasangan digunakan untuk mengetahui perbedaan antara sebelum dilaksanakan Program OK BOS dan saat dilaksanakan program terhadap angka kecelakaan yang terjadi. Hasil analisis uji beda berpasangan terhadap angka kecelakaan ditunjukkan pada Tabel 4.

Tabel 4. Hasil uji beda berpasangan angka kecelakaan berdasarkan jumlah kecelakaan

\begin{tabular}{|c|c|c|c|c|c|c|c|c|}
\hline & \multicolumn{5}{|c|}{ Paired Differences } & \multirow{3}{*}{$\mathrm{t}$} & \multirow{3}{*}{$\mathrm{df}$} & \multirow{3}{*}{ Sig. (2-tailed) } \\
\hline & \multirow{2}{*}{ Mean } & \multirow{2}{*}{$\begin{array}{c}\text { Std. } \\
\text { Deviation }\end{array}$} & \multirow{2}{*}{$\begin{array}{l}\text { Std. } \\
\text { Error } \\
\text { Mean }\end{array}$} & \multicolumn{2}{|c|}{$\begin{array}{l}\text { 95\% Confidence } \\
\text { Interval of the } \\
\text { Difference }\end{array}$} & & & \\
\hline & & & & Lower & Upper & & & \\
\hline $\begin{array}{r}\text { Pair } 1 \text { angka_laka_17_jmllaka } \\
\text { angka_laka_18_jmllaka }\end{array}$ & $-5,667$ & 77,010 & 18,151 & $-43,963 \mid$ & 32,629 & $-0,312$ & 17 & 0,759 \\
\hline
\end{tabular}

Uji hipotesis:

$\mathrm{H}_{0}$ : tidak terdapat perbedaan angka kecelakaan sebelum dan saat dilaksanakan Program OK BOS.

$\mathrm{H}_{1}$ : terdapat perbedaan angka kecelakaan sebelum dan saat dilaksanakan Program OK BOS.

Bila digunakan nilai $\alpha$ sebesar 0,05 dan nilai $\mathrm{v}$ sebesar 17 , diperoleh nilai $\mathrm{t}_{\text {tabel }}$ sebesar 2,110. Untuk uji ini, Ho ditolak jika |t| lebih besar dari 2,110 (atau bila nilai Sig. lebih kecil dari $\alpha$ yang digunakan). Hasil statistik uji t yang diperoleh adalah sebesar - 0,312, sehingga $\mathrm{H}_{0}$ tidak dapat ditolak. Dengan demikian dapat disimpulkan bahwa tidak terdapat perbedaan angka kecelakaan sebelum dan saat dilaksanakan Program OK BOS.

\section{KESIMPULAN}

Program OK BOS merupakan upaya Ditlantas Polda Jawa Timur dalam menggerakkan polres jajaran untuk berperan aktif dalam kegiatan aksi keselamatan jalan. Berdasarkan hasil analisis dengan tinjauan angka kecelakaan berdasarkan jumlah kejadian dapat ditarik kesimpulan sebagai berikut:

1. Implementasi awal Program OK BOS, pada periode Juni - Oktober 2018, memperlihatkan hanya terdapat 12 polres jajaran yang mengalami mengalami perubahan atau berdampak terhadap penerapan program keselamatan jalan ini di Jawa Timur.

2. Efektivitas implementasi awal Program OK BOS hanya terjadi di 20 polres jajaran, sementara di 19 polres jajaran yang lain tidak demikian.

3. Data kejadian kecelakaan polres jajaran selama implementasi awal program memperlihatkan bahwa tidak terdapat perbedaan yang signifikan antara sebelum implementasi program dan saat implementasi program. 


\section{REKOMENDASI}

Implementasi awal Program OK BOS yang dilaksanakan oleh Ditlantas Polda Jawa Timur sepanjang bulan Juni hingga Oktober 2018 masih belum menunjukkan keberhasilan dan efektivitas secara menyeluruh pada polres jajaran. Karena itu diperlukan langkah-langkah strategis untuk lebih memberikan penetrasi agar diperoleh keberhasilan implementasi program keselamatan jalan ini pada periode berikutnya. Rekomendasi yang dapat diberikan, antara lain, adalah:

1. Perlu disusun perencanaan secara komprehensif implementasi Program OK BOS untuk periode selanjutnya.

2. Sebelum implementasi tahap selanjutnya, perlu dilakukan workshop pada personil polres jajaran untuk meningkatkan kemampuan dalam:

a. optimalisasi pemanfaatan IRSMS dan interpretasi hasil analisis data kecelakaan pada IRSMS untuk dapat menentukan program kegiatan yang tepat.

b. perencanaan program kegiatan setiap polres jajaran dan penetapan indikator capaian kegiatan keselamatan jalan dan Program OK BOS.

3. Perlu dilakukan monitoring dan evaluasi secara periodik (misalnya setiap 3 bulan) oleh Direktorat Lalu Lintas c.q Subdit Kamsel, sebagai fungsi Pembina, terhadap setiap polres jajaran, sehingga dinamika implementasi dapat terbaca secara periodik dan dapat dilakukan upaya-upaya cepat apabila indikator kegiatan dan program belum tercapai.

4. Perlu dilakukan implementasi Program OK BOS atau program sejenis secara berkelanjutan guna mendukung Dekade Aksi Keselamatan Jalan.

\section{UCAPAN TERIMA KASIH}

Ucapan terima kasih disampaikan kepada Korlantas Polri yang telah memberikan kesempatan dan dana penelitian kepada Tim Peneliti. Terima kasih disampaikan pula kepada Direktorat Lalu Lintas Kepolisian Daerah Jawa Timur atas dukungan dan fasilitas yang diberikan dalam penggambilan data kecalakaan dan kegiatan aksi keselamatan jalan selama pelaksanaan penelitian.

\section{DAFTAR PUSTAKA}

Departemen Permukiman dan Prasarana Wilayah. 2004. Penanganan Lokasi Rawan Kecelakaan Lalu Lintas, Pedoman Konstruksi dan Bangunan Pd T-09-2004-B. Departemen Permukiman dan Prasarana Wilayah: Jakarta.

Hayati, N.N., Prasatya, I.M.A., Sulistyono. S. 2010. Evaluasi Pengkarakteran Lingkungan Jalan dan Peningkatan Patroli Lalu Lintas Pada Aksi Keselamatan Jalan Lokasi Blackspot. Simposium Nasional XIII Forum Studi Transportasi Antar Perguruan Tinggi (FSTPT) Indonesia. Jember: UPT Perpustakaan Universitas Jember.

Pemerintah Republik Indonesia. 2009. Undang-Undang Nomor 22 Tahun 2009 tentang Lalu Lintas dan Angkutan Jalan. Sekretariat Kabinet Republik Indonesia: Jakarta.

Pemerintah Republik Indonesia. 2013. Instruksi Presiden Republik Indonesia Nomor 4 Tahun 2013 tentang Program Dekade Aksi Keselamatan Jalan. Sekretariat Kabinet Republik Indonesia: Jakarta. 
Sulistyono, S., Soetjipto, J.W., Saputro. O.R. 2012. Analisis Efektivitas Program Partnership Road Safety Action (PRSA) Jalur Pantura Surabaya - Tuban. Prosiding Seminar Nasional Teknik Sipil 2012. Bandung: Universitas Kristen Maranatha.

Supriono, H., Sulistyono, S., Bustami. R.E.. 2010. Analisis Keselamatan Jalan Kawasan Tertib Lalu Lintas (KTL) Kota Jember. Simposium Nasional XIII Forum Studi Transportasi Antar Perguruan Tinggi (FSTPT) Indonesia. Jember: UPT Perpustakaan Universitas Jember.

Tjahjono, T. 2017. Upaya Peningkatan Keselamatan Pada Jalan Nasional Indonesia. Jurnal Transportasi, Vol.16, No.2. Forum Studi Transportasi Antar Perguruan Tinggi: Bandung.

World Health Organization. 2011. Decade of Action for Road Safety 2011-2020. http://www.who.int/roadsafety/en/. Jenewa: World Health Organization.

World Health Organization. 2013. Global Status Report on Road Safety 2013: Supporting a Decade of Action. WHO: Geneva, Switzerland 